العدد الثامن عشر(V V • ץ) الجزء الخامس

Title: The City as Represented in Teju Cole's Open City and Ibrahim Abdel Meguid's No One Sleeps in Alexandria

\author{
Rania Reda Nasr
}




\title{
The City as Represented in Teju Cole's Open City and Ibrahim Abdel Meguid's No One Sleeps in Alexandria
}

\begin{abstract}
:
Living in our global world today of migration and multiculturalism is living without boundaries but with differences. Diversity is thus a key feature of modernism and post-modernism. How do cities embrace these differences? How do we read the city? How does the city affect and define its inhabitants and migrants? How are writers inspired and overwhelmed by the city and how do they interpret their experiences in literary texts? What is the relationship between the city and the text? The aim of this paper is to read the city of New York and Alexandria in the literary works of Teju Cole's Open City and Ibrahim Abdel Meguid's No One Sleeps in Alexandria. The paper will explore how each writer reads his city and translates his experiences in the text. Wavering between two cities, "the city of feelings" and "the city of facts", Julius and Magd al-Din are wandering as strangers and flâneurs in the streets of New York and Alexandria. The paper follows their experiences of living with difference as they are being exposed to/by the city.
\end{abstract}

Keywords: city, flâneur, cosmopolitanism, friendship, diversity, Teju Cole, Ibrahim Abdel Meguid.

$$
* * * * * *
$$

Today, cosmopolis is conceived as a city of the world, or the world as city, composed of citizens who accept and tolerate each other, who cross boundaries and are aware of their interrelations. (Conley, "Chaosmopolis")

Lucy carried in her mind a very individual map of Chicago: a blur of smoke and wind and noise, with flashes of blue water, and certain clear outlines rising from the confusion ... The city of feeling rose out from the city of fact like a definite composition, - beautiful because the rest was blotted out. (Willa Cather, Lucy Gayheart)

Over the course of history, the city has been a complex and powerful source of inspiration for writers in different literary fields. ${ }^{1}$ Wavering between the "city of feelings" and the "city of facts", writers interpret their experiences in the literary texts as they are being exposed to/by the city. The aim of this paper is to read the city of New York and

\footnotetext{
${ }^{1}$ Writers like T.S. Eliot, William Wordsworth, Charles Dickens, John Updike, James Joyce, Italo Calvino and many others have been overwhelmed by their cities and translated their experience with the cities in their literary texts. For further information on the topic, see Richard Lehan, The City in Literature pp. 3-12; 26-50; 71-82; 104-166.
} 
Alexandria in the literary works of Teju Cole's Open City and Ibrahim Abdel Meguid's No One Sleeps in Alexandria. The paper will explore how each writer is overwhelmed and inspired by the city he represents and how they translate their experiences in their texts.

In his groundbreaking study, The City in Literature, Richard Lehan traces the development of the city, in its positive and negative senses, from the Age of the Enlightenment to those of modernism and postmodernism. Lehan's study encompasses "the ways the city has been conceptualized from its origins to the present time" (3). For him, the city is simply "the place where man and nature meet", and cities are established "to meet the basic needs of their inhabitants - the need to worship, to feel protected, and to find solace in the community" (13). According to Lehan, there are three ways by which historians conceptualized the city; some historians study the origins of the modern city:

cut off from a source of nourishment beyond itself, the city became a closed system, entropic, which led to the decline of civilization: instinct was sacrificed to reason, myth to scientific theories, barter of exchange to abstract theories of money. (6)

Other historians believed in the "physical laws" of the modern city and that it was "externally organized in terms of laws of its own" (6). The third group of historians, Lehan further states, focused on the "effect of the city on its inhabitants", and examined "what happens when the city becomes a state of mind" (7).

On his behalf, Burton Pike, in his critical study The Image of the City in Modern Literature, states that:

The city in Western culture has always been problematic. It is an artifact deeply rooted in our civilization and mind; there is no way of experiencing, observing, or writing about it which does not arouse strong feelings and vivid associations. The city always speaks and with many voices. (ix)

Despite its charm and power, negative viewpoints are sometimes associated to the city. In this respect, Lehan states, "As the city became more materialistic, it engendered a hostility in the literary imagination" (5). According to Lewis Mumford, "No matter how many valuable functions the city has furthered, it has also served, through most of its history, as a container of organized violence and a transmitter of war" 
(46). Other critics reduce the city to "the status of a container or backdrop of human activities" (Hubbard 2). Nevertheless, Pike states that:

[In spite of] the myth of the city as corruption, the myth of the city as perfection ... the image of the city stands as the great reification of ambivalence, embodying a complex of contradictory forces in both the individual and the collective Western minds. The idea of the city seems to trigger conflicting impulses, positive and negative, conscious and unconscious ... These conflicting resonances of the image are reinforced by a writer's and reader's own experience of city life, whether real or imagined. $(8,9)$

Accordingly, the city has triggered writers to "read" the city far beyond its physical and social fabrics and translate it into literary representations in texts. Lehan states that "the city and literary text have had inseparable histories, and reading the city is only another kind of textual reading (8)". On the relationship between the city and the text, Hana Wirth-Nesher argues that,

the 'real' city cannot be experienced without meditation ...; it is itself a text that is partly composed of literary and artistic tropes ... The city text is a palimpsest ... of the history of its representation in art, religion, politics - in any number of cultural discourses. (10-11)

Lehan further argues that the city became a "personal" experience within each "inhabitant caught in his or her own subjectivity (129)"; such a city, as both Lehan and Pike point out, is at once "a physical reality and a state of mind" (Lehan 287; Pike 4).

According to Pike, the writer looks at the city from three viewpoints, "from above, from street level, and from below (34)". When the writer looks at the city from above he is uninvolved with the daily city life, he contemplates it in a detached attitude; where to see the city from below is to "demonize" it. Pike argues that the most common vantage point for writers in looking at the city is from street level, "a fixed place, rich in resonances of all kinds ... [in which the] writer's own psyche is involved" (35). Thus, the city is no longer represented as a static space whose stones and buildings stood in fixed relationship to each other, but it presented "an irritable nervous energy" (Pike 72) where the image of the city as the "paved solitude" stands as the paradigm of modern literary expressions of the city; it is the way in which "the character or narrator typically presents himself alone against the city, an isolated individual consciousness observing the urban community" (15). Pike further argues that the city, which in earlier times had predominantly been the image of 
"fixed relationships and fixed elements", has become an "image of flux, of dislocation rather than location" (17). In this sense, Lehan states:

The city, once an Enlightenment ideal, was being questioned in romantic, modern, and postmodern thought. A sense of being at home in the city was replaced by its opposite - the 'unhomely,' expressed as the uncanny and often embodied by the outsider, the Other, the mysterious stranger, or the lonely man in the crowd. (xv)

It is in this city that we meet strangers and flâneurs both in the "city of facts" and the "city of feelings". The flâneur is the wanderer, the observer who finds in the crowd "an object that triggers his imagination and memory" and whose state of mind is "restless dissatisfaction" (Lehan 72, 74). In his critical study, "Expressions of the City", Ivy Lai Chun states that "the city is full of strangers. Everywhere you look, every sheer sense of unfamiliarity culminates in the crowds. The insecurity of the crowd lays birth to strangers and flâneurs"(13). The flâneur has in fact become "a key figure in the critical literature of modernity and urbanization" (Wilson 93). ${ }^{2}$

Representing the figure of the flâneur, Teju Coles's debut novel, Open City, takes place in the cosmopolitan "open" city of New York. ${ }^{3}$ The novel opens with the "aimless wanderings" (3) and meditations of a Nigerian-German psychiatrist, Julius, roaming the streets and public transportations of New York. Representing the popular figure of the nineteenth century flâneur, Julius's wanderings "generate a perspective that is both intimate and detached, engaged as well as estranged" (Pieter, 41). Reflecting the city of facts, Cole engages his reader in the streets and monuments of New York as Julius wanders through Manhattan, Central Park, Times Square, Brooklyn Bridge and the site of the events of 9/11 from Wall Street to the World Trade Center. Julius notes that " $[t]$ he site was a palimpsest, as was all the city, written, erased rewritten" (58-59). Moving beyond the stones and buildings of New York, Julius merges within the crowds as his walks become a "counterpoint" to his busy days at the hospital (3). Julius observes, "New York City worked itself into my life at walking pace ... it became the normal thing, and I forgot what life

\footnotetext{
${ }^{2}$ The figure of the flâneur first appeared in the $19^{\text {th }}$ century by Charles Baudelaire and Walter Benjamin wandering through the streets of Paris. The flâneur further appeared in : Joseph O'Neill, Netherland (New York: Pantheon, 2008); Ben Lerner, 10:35 (New York: Macmillan, 2014); W.G. Sebald, Austerliz, trans. Anthea Bell (New York: Modern Library, 2001).

${ }^{3}$ Teju Cole is a Nigerian-American writer, photographer and art historian, born in 1975 . He is the author of four books, a collection of more than forty essays and a volume of photographs. He has won many awards for his novel Open City including the Hemingway Foundation/Pen Award.
} 
had been before I started walking" $(3,7)$. Although he searches for himself and for connections to the city, Julius cannot overcome his "feelings of isolation" (6). This recalls Walter Benjamin's observation that the flâneur "seeks refuge in the crowd" yet continues to feel isolated and alienated by modern society; in that sense he/she is simultaneously "outside and inside" (40). Embodying the figure of the observant and isolated flâneur, Julius states:

I encountered the streets as an incessant loudness ... walking through busy parts of town meant I laid eyes on more people, hundreds more, thousands even, than I was accustomed to seeing in the course of a day. But the impress of these countless faces did nothing to assuage my isolation; if anything, it intensified them ... The sight of large masses of people hurrying down into underground chambers was perpetually strange to me, and I felt that all of the human race were rushing, pushed by a counter-instinctive death drive, into movable catacombs. Aboveground [sic]I was with thousands of others in their solitude, but in the subway, standing close to strangers, jostling them and being jostled by them for space and breathing room, all of us reenacting unacknowledged traumas, the solitude intensified. (6-7)

In The Black Atlantic, Paul Gilroy argues that people of African origin communicate through a "code" or "bond" based upon "blackness" through a shared "tradition" (191). Connoting these racial bonds in the novel, Julius states,

There had been, it occurred to me, only the most tenuous of connections between us, looks on a street corner by strangers, a gesture of mutual respect based on our being young, black, male; based, in other words, on our being "brothers". These glances were exchanged between black men all over the city every minute of the day, a quick solidarity worked into the weave of each man's mundane pursuits, a nod or a smile or quick greeting. It was a little way of saying, I know something of what life is like for you out here. (212)

Yet, Julius's exposure to the people in the city intensifies his solitude and he finds himself unconnected and unattached to people or places in the city. At the beginning of the novel, we see Julius choosing internet stations far away from Canada and the Netherlands simply because their voices are "speaking calmly from thousands of miles away" (4). Moreover, he rejects being identified to or claimed by any "brother" of his fellow men. For example, in the scene of the taxi driver who is 
offended by Julius for not greeting him as "fellow" and who, by turn, tells him, "you know, the way you came into my car without saying hello, that was bad. Hey, I'm African just like you, why you do this?"; recalling this scene, Julius notes, "I wasn't sorry at all. I was in no mood of people who tried to lay claims on me" (40). Having no desire to abide by bonds built upon presupposed "solidarity", Julius was not pleased at another incident meeting a museum guard who approached him feeling connections to a dark-skinned man like himself. Julius notes, "I wished he would go away ... I thought of the cabdriver who'd driven me home "hey, I'm African just like you. [The guard] was making a similar claim" (53). Furthermore, when Julius visits a post office he encounters another African-American worker who notices his Nigerian accent and refers to him as "Brother Julius" and keeps talking to him about "Motherland" (186). Unpleased, Julius made a "mental note to avoid that particular post office in the future" (188). Resisting all these expectations of identifications and pressures of assimilation based upon race or color, Julius ends up feeling isolated and unconnected to Africans as well as to Americans. Denying the "need for rootedness," (Dalley 19) Julius cannot identify himself as an African in America, or as an American in Africa or Europe. The same uneasiness is felt when Julius visits Brussels and meets Farouq, the café owner, who asks, "you must be from America". Although Julius acts as an "outraged American" during a political discussion about 9/11 (120), he never refers to himself as an American when introduced to other immigrants. At the same time, because of his German roots, Julius feels an outsider in Nigeria where,

[t]he name Julius linked me to another place and was, with my passport and my skin color one of the intensifiers of my sense of being different, of being set apart, in Nigeria ... Being Julius in everyday life thus confirmed me in my not being fully Nigerian. (78)

According to Dalley, Julius represents "a man who resists the pressure of collective identification, objecting to the beliefs that accidents of birth, race or family should entail ethical obligations" (26). Bernard Oniwe, however, argues that as "Julius represents a cosmopolitan aspiration to a worldliness not constrained by race, religion or nation", he subsequently challenges the cosmopolitan ideal of living in a global world of difference (46).

In his critical study, After the Cosmopolitan?, Michael Keith states:

Across the globe, citizens of the metropolis are asking themselves 'how do we live with difference?', as the problem of 
multiculturalism poses a challenge to the way in which people make sense of their own lives. (Keith 38)

In the same context, Philip Kasinitz argues that "to live in the modern city means to live in the presence of difference. For better or for worse, it requires frequent interaction with those who probably do not share one's beliefs and values"(3). As he longs to protect his solitude, Julius expresses his desire to "find a line" connecting him to the people and the city. He notes in a brilliant passage where the subway is used as symbolic of our post-modern life,

Generations rushed through the eye of the needle, and I one of the still legible crowd, entered the subway. I wanted to find the line that connected me to my own part in these stories. (59)

In the subway, with its association with death and the underground world, people's remoteness is intensified by their closeness, and the "lines", which are supposed to connect, only takes people apart with an appalling speed.

The claustrophobia of the subway is repeated in the night club for a different reason: Julius was shocked as he realizes that the night club he visited was full of Rwandans. He states, "The realization that I was with fifty or sixty Rwandans changed the tenor of the evening for me. It was as though the space had suddenly become heavy with all the stories these people were carrying (126)". Being close in terms of space to these Rwandans, irritated Julius, who preferred to stay remote in fear of hearing stories he may not tolerate. The same paradox of remoteness in spite of sharing the same city space is highlighted in the episode of Julius's dead neighbor: Julius experiences a "belated shock" (20) as he accidentally knows that his neighbor's wife had died a few months ago:

A woman had died in the room next to mine, she had died on the other side of the wall I was leaning against, and I had known nothing of it ... I had noticed neither her absence nor the change in his spirit ... I had known nothing in the weeks when her husband mourned, nothing when I had nodded to him in greeting with headphones in my ears. (21)

Julius's sense of indifference and disconnection as well as his refusal to being "claimed" by any group exposes the "apparent celebration of the exemplary cosmopolitan figure of the flâneur" (Pieter 40). Providing 
experiences of "shared isolation" the novel, according to Pieter, "interrogates" rather than "affirms" cosmopolitan diversity (47). ${ }^{4}$

The novel, Open City, poses the question: "What happens when a city is invaded by new waves of immigrants: is it conceived to be the same city, a different one, and in what degree, and by whom?'(Strauss 520). The open city of New York represents a cosmopolitan space hosting immigrants from Africa, Asia and the Hispanic race as they come together and seemingly interact efficiently and peacefully embracing the cultural differences among them. On a single day, you can meet a Japanese professor, a Mexican nurse, African cab driver, guard from Barbuda, Caribbean shoe shiner, Czeck woman in the café, and others from Haiti and Liberia.

The city, thus, is open to new people and new ideas, open to differences and diversity. However, the scenes of violence that pervade the novel expose the failure of New York city to become a paradigm of cultural tolerance..$^{5}$ In this sense, Pieter states that " $[t]$ he panorama of cultural and historical differences that the novel develops is mainly made up of scenes of violence, abuse, and exploitation, almost always tinged by a racist component" (44). Describing his experience at a music concert, Julius reveals how he moves from the realm of the city of feelings to that of the city of facts as he becomes the subject of the "gaze" of white men and women at the concert. Racism is revealed both as a constant daily practice and as part of the palimpsest of the "Open" city, which is in fact close to many of the flâneurs who "invade" it. Experiencing racism in New York, Julius notes:

It never ceased to surprise me how easy it is to leave the hybridity of the city, and enter into all - white spaces, the homogeneity of which, as far as I can tell, causes no discomfort to the whites in them. The only thing odd, to some of them, is seeing me, young and black, in my seat or at the concession stand. At times, standing in line for the bathroom during intermission, I get looks that make me feel like Ota Benga, the Mbutti man who was put on display in Monkey House at the Bronx Zoo in 1906. I weary of such thoughts, but I am

\footnotetext{
${ }^{4}$ It is worth noting that, ironically, Cole never refers to New York as the "open city"; but the phrase was only used as Julius coins it to Brussels whose rulers had saved their country from war by surrendering (97). This note thus emphasizes the failure of New York to achieve this cosmopolitan ideal.

${ }^{5}$ The novel recounts the American persecution of the Japanese population driving to the Second World War, the violent suppression of natives by Dutch settlers, the sufferings of Indians, the 9/11 catastrophe, along with "the echoes across centuries, of slavery in New York" (Open City 221).
} 
habituated to them. (252)

According to Lehan,

Diversity is a key to urban beginnings and continuities, and diversity is also the snake in the urban garden, challenging systems of order and encouraging disorder and chaos ... such diversity led inevitably to the 'Other' - an urban element, usually a minority, deemed 'outside' the community. (8)

Representing the "Other" in his/her isolation and unbelonging, Julius fails to connect to the city, neither by birth nor by residence. In this respect, Oniwe states:

Globalization as an agent of human and ideological mobility can be credited with hastening the decay of national boundaries and the resultant interaction and mingling of people of different national and cultural allegiances ... [which] has led to more and more people refusing to be restrained by a parochial view of others. (43)

We encounter this challenge to the "cosmopolitan ideal" not only in New York but also beyond borders in Brussels. Dismissing modern concepts of "melting pot, salad bowl, multiculturalism," Farouq states, "I reject all those terms. I believe foremost in differences"(114). Recounting his own experience as an immigrant to Europe, Farouq states:

When I was young, Europe was a dream. Not just a dream, it was the dream: it represented the freedom of thought. We wanted to come here, and exercise our minds in this free space ... But I have been disappointed. Europe only looks free. The dream was an apparition. (122)

Cole, once again, exposes the failure of the city to offer a space for the "Other"; Brussels, like New York, fails to allow for coexistence between different people; he further emphasizes the hypocrisy of these cities as representing the ideal value of tolerance. As the narrative unfolds, images of cultural intolerance are intensified - beginning with Julius's unbelonging and unconnectedness and ending with the final image of the Statue of Liberty, exemplified by the image of thousands of birds killed at the symbolic statue of freedom as they pass by its flame. The "miracle of natural immigration" that Julius foreshadows at the very beginning of the novel(4), thus, dies at the very symbol of freedom: 
The birds, many of which were clever enough to dodge the cluster of skyscrapers in the city, somehow lost their bearings when faced within a single monumental flame. (259)

The birds' analogy somehow cautions the reader to the fake image of the openness of the city, of the cultural tolerance embracing differences. Immigrants eventually fall into the hypocrisy of the so-called "cosmopolitan differences". The novel also ends upon Julius's sense of unbelonging, of his inability to see the stars and the light; on his refusal to fall into the traps of assimilation of any kind. Julius states,

$\ldots$ in the dark spaces between the dead, shining stars, were stars I could not see, stars that still existed, and were giving out light that hadn't reached me yet, stars now living, and giving out light present to me only as blank interstices. (256)

Alexandria, on the other hand, is read differently by Abdel Meguid in No One Sleeps in Alexandria. ${ }^{6}$ Traditionally, Alexandria has always been identified as a city with a long history of cosmopolitanism. ${ }^{7}$ According to Robert Mabro, "A cosmopolitan Alexandria emerged around 1850 and virtually disappeared in the 1960s or soon thereafter" (247). Developing as a cosmopolitan city, Alexandria experienced a colonial hegemony of the Ottoman, French and British rule. Immigrants came mainly from various European countries such as Greece, Italy, and the Levant (Syrian, Lebanese, Armenians and Jews), and settled in Alexandria, "this big white city, which accommodated all these people from all over the world, without complaining" (Alexandria 144).

Ibrahim Abdel Meguid's No One Sleeps in Alexandria focuses on the Second World War, foregrounds Alexandria, and describes the daily life and the struggles of its inhabitants during the war. Alexandria is being "re-imagined" in Abdel Meguid's novel as he revives the

\footnotetext{
${ }^{6}$ Ibrahim Abdel Meguid was born in Alexandria in 1946. He is one of Egypt's most respected and well-known authors celebrated for his International Prize for Arabic Fiction (IPAF)longlisted novel, Clouds Over Alexandria. He also won the Naguib Mahfouz Medal for The Other Place. He has authored more than twelve novels and six collections of short stories, all set in Egypt during particular historical periods, with many translated into French and English. Obsessed with the city in his writings, Abdel Meguid states in an interview with Mohga Hassib that "The hero is the city".

${ }^{7}$ Among many important writers identified with Alexandria is C.P. Cavafy, a native Greek son who is known as Alexandria's Poet, or "the poet of the city", Lawrence Durrell, and Edwar al-Kharrat.
} 
cosmopolitan nature of the city throughout the "trauma of modernization" (Abdel-Messih 94). Deborah Starr argues that since the 1990s there has been a revival of interest in Alexandria's modern cosmopolitan past. She states:

From its foundational narratives to contemporary nostalgia literature, Alexandria has been imagined as a cosmopolis, an urban space where peoples and cultures come into contact. ("Recuperating Cosmopolitan", 217)

The novel, according to Starr, depicts the development of a strong friendship between a Muslim and a Copt who work on railway lines in Alexandria, men whose "interfaith friendship stands on the vanguard of the defense against Rommel's troops and Nazi intolerance" (Remembering Cosmopolitan, 59). As the novel advocates this "interfaith" coexistence, it also makes use of the cosmopolitan mix of Egyptians - men and women of various ethnicities, regions, and religions - and weaves out of these relationships a new fabric of the city.

The main character in No One Sleeps in Alexandria is Sheikh Magd al-Din, a devout Muslim farmer who is exempted from military service because of his achievement of memorizing the entire Quran. He and his wife, Zahra, and his young daughter are compelled to leave their home;the mayor of the village forces Magd al-Din to migrate, leaving behind his home and land because of a blood feud between the two families, the Khalils and the Talibs, which had lead to the death of eleven members of both families. Abdel Meguid, thus, intertwines the local with the global migration to Alexandria as the narrative unfolds. As Magd al-Din and his family leave their village, migrating to Alexandria, we meet soldiers coming from all over the world: "English, Irish, Scottish, South African, and Australian, in addition to Greek, French, and Jewish volunteers," (Alexandria, 262) to settle in Alexandria. Embracing this diversity, Alexandria thus offers a space for cultural tolerance and peaceful coexistence.

Parallel to the Second World War, local retaliations take place; battles between upper and lower class Egyptians, northerners and southerners. Moving between facts and fiction, the novel begins with a scene in Berlin, days before the German invasion of Poland, marking the start of World War II in Europe. While most of the novel focuses on a few characters living in Alexandria, Abdel Meguid returns every now and then to world 
events, many of which have an immediate and direct impact on his characters. Hitler's planning to attack Poland runs parallel to the bloody feud between the two families. As Germans are moving into Poland; European and African migrants are moving to Alexandria, the city which was supposed to embrace all these diverse immigrants.

In his account of Alexandria, Abdel Meguid presents various characters - Muslims and Christians, men and women, natives and immigrants - who interact with each other and build strong relationships. Moreover, Abdel Meguid's city, like that of Teju Cole, is a palimpsest of diverse layers. As a palimsest, , however, Alexandria is way more dense and thick . The chapters of the novel are prefaced by fragments from Pharaonic, Coptic, Islamic, or Indian sources; which reveal the sociopolitical, cultural and religious fabric of the city. Abdel Meguid foregrounds different bonds in his narrative: neighbourhood and "civic friendship" in the community; personal friendship, and love. By weaving them together, Abdel Meguid provides us with the strong structure of the Alexandria society in response to the political tensions on the local and global levels. Alexandria's space thus allows for cross-cultural and crossethnic relationships to live in harmony, advocating thus cultural and religious tolerance that is missing in Open City.

Magd al-Din and his family arrive in Alexandria and move in with his brother Bahi, who has lived in the city since he finished military service. The novel traces the lives of Magd al-Din and his family, his Christian neighbors in the building and other immigrants from different backgrounds who meet as they get settled in their new home. The city is affected by the global war; the lives of its inhabitants are disrupted by shortage of food; lack of job opportunities; troop movements; and frequent air raids. Under these circumstances, both Magd al-Din and his close friend Dimyan,another Coptic Christian are looking for work in a city "that was boiling on top of a volcano" (45). After a series of shortterm jobs, they are assigned to permanent employment at the railway station at al-Alamein, the site of the famous World War II battle that is described as "[the] land of war, [the] land of death. . .[a] horrendous wilderness [that] would swallow everything" (Alexandria, 253). However, it is in this wilderness and despite the war scenes that Magd al-Din and Dimyan's friendship develops. It is interesting here to note that the railway is used by Abdel Meguid as a symbol of connection/separation, in the same manner as the subway is used in Cole's Open City. 
Central to the novel is the story of the friendship between Sheikh Magd al-Din, the local immigrant with peasant roots in northern Egypt; and Dimyan, the native Alexandrian with roots in southern Egypt. Woven around this narrative are the stories of other characters in the city, village, or in the faraway desert. Despite the ongoing battles between the Khalils and the Talibs, Abdel Meguid introduces the friendship between Magd alDin and Khalaf, the last members of each family. "This friendship," the narrator tells us, made each do his best to avoid facing the other in battle" (7).

Aristotle uses the Greek word philia, that is translated as friendship, in broader senses through relationships within members of religious, social or political organizations. The central idea for him is the "mutual well-wishing and well-doing of concern for one another"; it is the friendship of "good persons" who are "good and alike in virtue" (NE, 1157a20, b25). Aristotle devotes much of his Nicomachean Ethics to celebrating male/civic friendship. He states, "we may even see in our travels how near and dear every man is to every other" (NE, 1155a21). According to Aristotle, every person needs to have close personal relationship built up on common and shared activities. In the society, he argues, people experience a form of friendship for each other in the sense that they wish each other well for their own sake and share in values and goals. On the political importance of friendship, Aristotle argues that friendship creates a unified community composed of unified selves: "For friendship is community, and we are related to our friend as we are related to ourselves" (NE, 1171b30-35). He further states,

Friendship seems to be the bond that holds communities together, and lawgivers care more for it than for justice; ... when men are friends they have no need for justice, while when they are just they need friendship as well. (NE, 1155a23-28)

Schwarzenbach differentiates between two types of friendships: the the civic or political and the personal. In civic friendship, intimate knowledge and a close emotional bond are absent. It is a state where "one can assume no ties of intimacy, of individual knowledge, or of personal affection" (Schwarzenbach 106). According to Schwarzenbach, civic friendship does not entail that both friends should be of the same religion or race, but only they must share a sense of justice and possess a general good will and concern for the moral character of their friends.

Schwarzenbach further argues that "tolerance" is the key feature of civic friendship and by which citizens acknowledge "universal principles of respect" between each other (Schwarzenbach 114). This civic friendship is what held Alexandria together: 
Among the foreigners were hundreds and thousands of adventurers, who came to the cosmopolitan city and made it a virtual tower of Babel. Among the Egyptians were thousands of castaways, like Magd al-Din, who preceded and would follow him. The north of the city was no longer enough for the foreigners, so the poorest of them - Greeks, Jews, Italians, and Cypriots - moved to some of the poorer neighborhoods, such as Attarin and Labban. They moved closer to and mixed with the Egyptians, who lived in the south of the city. Magd al-Din had arrived in an Alexandria that was on top of the world. In addition to the European residents, there were soldiers from Europe and all the Commonwealth - and he, the expelled peasant. (45)

Peaceful coexistence is highlighted in many scenes in the novel. For example, the same night that Zahra and Magd al-Din arrive in Alexandria, Zahra is surprised to hear that there is no real and threatening tension between Christians and Muslims but "the real tensions were between northern and southern Egyptians" ( 33). The following day after renting a room next to Khawaga Dimitri, their Coptic neighbor, Zahra goes and meets her new neighbor "Sitt Maryam and her two beautiful daughters, Camilla and Yvonne", and she immediately bonds with them (35). Moreover, Dimitri and his wife greet Magd al-Din and his wife Zahra and wish them well in Ramadan. Feeling welcomed in the big city by their neighbors, Magd al-Din tells Dimitri "You make me fall in love with Alexandria" (73). In this respect, Starr states,

[T] he novel foregrounds the diversity of Egyptians living in the 1940s in Alexandria: Muslims and Copts, longstanding residents and newly arrived migrants, sa 'ayda and fellahin. This diversity of Egyptians is more significant to the novel than the city's 'cosmopolitan' nature evident in the Western literary myth of Alexandria. (61)

In his representation of Alexandria, Abdel Meguid strikes a balance between the "city of facts" and "the city of feelings". Zahra wanders the streets and markets of Alexandria with Sitt Maryam going to Karmuz, Khedive Street, Attarin and then to al-Laythi street which is "the most famous street for antiques in Alexandria" (41), such trips in which characters view the city from the "street level". In addition to this "city of facts", we are introduced to "the city of feelings" as Umm Hamidu starts telling her stories of Alexander the Great and King Farouk: 
Thus after having seen the sea and the big squares with Sitt Maryam, Zahra entered Alexandria's magic world. Umm Hamidu's stories have given the city. . . a warm soul in winter that now appeared truly frosty. (182)

Zahra has much fun as she visits her neighbors Lula and Sitt Maryam, and her two daughters, Camilla and Yvonne. They enjoy their time together, talking, listening to songs and eating sugar cane. When Zahra shows surprise to the incident, Yvonne remarks that "[t]his is an ancient Egyptian custom - it's neither Islamic nor Christian. Our ancestors, the pharaohs, used to chew sugar cane on this occasion" (101). Once again, by highlighting this Pharaonic tradition, Abdel Meguid asserts that it is the city that embraces all these differences.

Set during the Second World War, the local and global migration, and the co-existence of Muslims and Copts, Abdel Meguid's message of the solid civic unity that overrides religious differences thus recalls Aristotle's theory of friendship. The novel is prevalent with scenes of 'interfaith co-existence,' reflecting Muslims and Copts sharing different religious traditions: For example, the coincidence of Muslim and Coptic feast days that Abdel Meguid interprets as a "divine blessing"; and the braiding of verses from the Quran and the Bible between Magd al-Din and Dimitri in the shelters during the raids, convey a powerful image of Alexandria as a city that embraces diversity.

Unlike Julius who rejects any bond with his fellow men, Magd alDin searches for solidarity of any kind. Before meeting Dimyan, Magd longs to find someone "to take him by the hand in the city" as his own brother "was no longer good for anything-he spent all day in the café"(48). When his brother, Bahi, dies in a street fight, Magd al-Din helplessly stretches his hand for support from anyone in the street to lift him from the ground: "Give me a hand, brother" (58; emphasis added). By coincidence, Dimyan appears and gives Magd a hand of support, beginning thus their life's friendship:

From time to time he [Magd al-Din] would catch himself looking around for someone and always found Dimyan, who never left his side ... and so as days passed, employed or unemployed, that huge area in the south of Alexandria became the daily arena of Magd alDin and Dimyan, a painful arena from which he came back longing for something beautiful. (107) 
Magd al-Din and Dimyan reflect Abdel Meguid's reading of the city within a multiple and diverse cultural and religious hegemony.

Despite the fact that both represent opposite ends, Dimyan, a Coptic from southern Egypt, and Magd al-Din (a Muslim from northern Egypt); they offer a unique example of the positive side of diversity. For example, Magd al-Din decides to fast with Dimyan saying, "I'll eat what you eat and abstain from what you abstain from" (270); On the other hand, when Ramadan comes, Dimyan decides to fast with Magd al-Din who tries to convince him that fasting is hard and that he is not used to it. But he tells Magd al-Din, "That's better than each of us eating alone in the desert" (278). Wandering together in the city from one place to another searching for a job, their bond of solidarity is intensified by economic conditions. As the war and the air raids on the city intensify, Abdel Meguid engages the reader in their developing friendship as they talk and exchange information about war, religion and the city. Magd al-Din "looked at him in amazement and admiration, and felt genuine warmth toward him" (71). We see them sharing experience as they walk every day and jump over fences, falling and laughing:

The two proceeded like two merry children toward the fence in the south ... Magd al-Din fell down on his backside, and Dimyan's chest hit the wall, and both felt great pain where they fell. But a few moments later they overcame the shock of the fall, they were now facing each other, and they both laughed happily: the two solitary men in a huge open space laughing without an echo. $(115,116)$

As the story unfolds, we see Magd al-Din as doubly displaced; first from his village and then in the desert of al-Alamein, which, as already pointed out, stand for war. However, it is this wilderness of the desert that offers a space for their friendship to develop. When Magd al-Din tells Dimyan to go to Alexandria to his wife, Dimyan simply tells him, "And leave you here?" (271). Abdel Meguid further portrays this emotional scene through Dimyan's meditation:

But Dimyan realized that he would not be able to go. It was not easy for him just to leave Magd alone in this wilderness. What a beautiful feeling he had for his friend ... But his love for Magd was a strong reason, there were no two ways about it... He had no life away from Magd al-Din. $(272,320)$

On his side, Magd al-Din thinks:

How great the Creator who controls all of this and who had sent Dimyan his way to make his days easy, even though he was in a 
place that even monkeys would flee from out of boredom ... with

Dimyan, it was possible for days to pass; without him, a total silence. (277)

Separating from Brika, the Bedouin girl that Dimyan falls in love with, arouses within him a greater need for Magd al-Din's friendship. He thinks, "How he needed Magd al-Din to give him confidence in longevity!" (302). When Magd al-Din's wife, Zahra, had to leave him alone in Alexandria to give birth in the village, we further realize the strong bond of his friendship with Dimyan:

He felt his heart wrenched. The world had become vast, white shaking mass with a distant sky, and he was a little child, crying sadly like an orphan ... had Dimyan not appeared ... Magd al-Din saw him and felt some consolation. He went toward him. This friend of his was the only one who could dispel his sorrow. (226)

Intersecting the storyline of the Magd al-Din /Dimyan relationship, is the love story between Rushdi and Camilla, another example of cultural and religious diversity in the city. Rushdi tells Camilla, "you're Christian - you're wearing a cross. I'm a Muslim. That's how it is. Where will it lead? I don't know (123)". She in return tells him: "You're from northern Egypt, Rushdi - you don't know what southern Egyptians are like. Besides, in this case it's a compounded problem, a difference in religion, and violation of southern Egyptian customary behavior (124)". Meditating on his love to Camilla, Rushdi thinks, "Who would believe this was his first love experience? It began at an incredible speed, with an incredible girl in her simplicity, beauty, and religion. Who remembered religions now? She was laughing as the sun behind her lit the world around her delicate body" (201). However, the religious, cultural and social traditions of the city forbid their love as their relationship "interrogates the institutional Muslim/Christian binaries" (Abdel-Messih 5). Camilla is sent by her family to a convent while Rushdi's wanderings over the whole landscape of Egypt looking for his beloved "awaken[s] the poet from his deep sleep" (311). Debunking this religious intolerance, Abdel Meguid demonstrates how Dimitri is rejected by the two religious communities in Alexandria; he becomes a social outcast: "'The Christians don't like him because he didn't know how to bring up his daughter, and the Muslims don't like him because he broke the poor boy's heart"' ( 224-25). Despite the pain and frustration caused by the failure of the Rushdi/Camilla love relationship, Abdel 
Meguid introduces friendship as more tolerant and embracing to religious and social differences.

Once again Abdel Meguid takes us back to the core of his narrative, the Magd al-Din/Dimyan friendship; they leave al-Alamein and take the train back to Alexandria. Feeling thirsty, Magd al-Din leaves the car to fetch water; he comes back at the sound of the explosion that has hit the car in which Dimyan is seated, leading to his death. Magd al-Din falls in total shock and despair, "He sat down on the nearest seat, sweat pouring from his skin as if a fire were burning in his chest. He stretched out on the seat and took off his shoes, leaning against the walls of the train car, realizing for the first time that he had become an orphan" (343).

As Hammond and Jablow argue in their study about male friendship, "the death of one friend and the overwhelming grief of the survivor is a theme that occurs frequently in the heroic tales ... it is here that the spiritual bond achieves its most poignant expression" (248). As Dimyan dies and Magd al-Din outlives the explosion, the latter begins a miserable life without his friend:

The month of Ramadan had begun, and the sorrows of Magd al-Din, who lay helpless in bed, increased. True, he had his family around him now, but he could not forget the previous Ramadan in the vast desert with its awesome sunsets, and breaking the fast with Dimyan. Dimyan! Dimyan! How could life go on without Dimyan! (347)

In this respect, Marie-Therese Abdel-Messih states that Magd alDin undergoes a "traumatic experience of loss ... By reckoning the other as part of him, Magd al-Din is released from sectarian limitations"(8). Thus, Magd al-Din and Dimyan's friendship overcomes the hegemonic oppositional binaries between Muslims and Copts; north and south in the unifying city of Alexandria. This relationship could be read as a proof of the capacity of political friendship to override social hierarchies and undermine cultural and religious barriers. In this respect, Drury Sherrod argues,

By acknowledging their need for intimacy, and risking the pursuit of friendship, men can begin to achieve the kind of closeness that males have known in other times and other cultures... With commitment and persistence, men can learn to break through the bonds that confine them and rebuild the bonds that unite them. (238, 239)

Friendship, whether personal or civic, succeeded in transcending traditional social values; religious differences; and political boundaries, in 
the city of Alexandria in spite of local feuds and international wars that continued to form and reform the palimpsest of the city.

Abdel Meguid's Alexandria, as Abdel-Messih rightly points out, is the "voice of a diversified community. It abounds with tales and accounts of war and peace, displacement and return, all narrating Alexandria's biography" (3). Despite the city's bleak world of war and violence, friendship provides a means for bridging differences. Abdel Meguid's No One Sleeps in Alexandria thus offers a space for this friendship in the city to balance obliterating social binaries, religious bigotry, and international wars. Whereas Julius refuses to see the light and the stars at the end of Open City, No One Sleeps in Alexandria ends on a note of hope. At one point, Zahra starts "seeing things with new eyes, imbued with an energy she had gotten from the city ... in which she was now living and loving;" (142). Magd al-Din decides to live permanently in Alexandria with his family; He eventually sees it "a city of silver with veins of gold" (Alexandria, 354).

$* * * * * * * * *$

To conclude, both New York and Alexandria are cosmopolitan cities welcoming migrants from all over the world; but as one city is reflected as challenging the cosmopolitan ideal, the other is embracing it. Moreover, the effect of these cities on its inhabitants is viewed differently in the two texts under study. In Cole's city, Julius wanders "aimlessly" as a flâneur, isolated and detached, rejecting any solidarity or ties of any "claims". In Abdel Meguid's city, on the other hand, men wander together longing for bonds which help them survive war and overcome solitude in the big city.

Whereas Cole's New York fails to tolerate differences in Open City which exposes the challenges and the limitations of the cosmopolitan ideal, Abdel Maguid's Alexandria overrides these differences. Both writers reveal the city as a palimpsest, where layers of events cover previous ones, while the latter continue to remain visible. Yet, unlike, Cole's Open City, Abdel Meguid's open city in No One sleeps in Alexandria embraces diversity through the developing themes of civic friendships between Muslims and Copts, northerners and southerners, natives and immigrants.

Throughout history, cities rise and fall but cities never die. They might be destroyed or plagued but "new cities will continue to be born" (Pike, 128). Whether challenging or celebrating the cosmopolitan ideal, both Teju Cole and Ibrahim Abdel Meguid enabled us to see "the city of feelings" as well as "the city of facts". Inspired and overwhelmed by their 
cities, both went beyond boundaries, and helped us to open each city, and to see its people, its culture and its history. They both prove Oniwe's idea that, in literary texts, people may achieve "the cosmopolitan ideal of openness to difference, both cultural and religious" (Oniwe 47). This paper has revealed that cities will continue to be built and rebuilt, memorized and expressed, at least or foremost, in literary texts. 


\section{Works Cited}

Abdel Meguid, Ibrahim. No One Sleeps in Alexandria. 1996. Trans.

Farouk Abdel-Wahab. The American University Press, 1999.

Abdel-Messih, Marie-Therese. "Alternatives to Modernism in Contemporary Egyptian Fiction: Ibrahim Abdel Meguid's No One Sleeps in Alexandria". The International Fiction Review, vol.32, no.1/2 (2005).

Aristotle. The Nicomachean Ethics. Trans. Terence Irwin. Indianapolis: Hacket, 1985.

Benjamin, Walter. The Writer of Modern Life: Essays on Charles Baudelaire, ed., Michael W. Jennings. Cambridge: Harvard University Press, 2006.

Cather, Willa. Lucy Gayheart. New York: Vintage, 1995.

Chun, Ivy Lai Chun. "Expressions of the City". Interdisciplinary Humanities, 32.3, (2015): 13-31.

Cole, Teju. Open City. London: Faber \& Faber, 2011.

Conley, Verena Andermatt. "Chaosmopolis". Theory, Culture and Society, 19 (1-2), (2002): 127-138.

Dalley, Hamish. "The Idea of 'Third Generation Nigerian Literature': Conceptualizing Historical Change and Territorial Affiliation in the Contemporary Nigerian Novel". Research in African Literatures 44.4, (2013): 15-34.

Gilroy, Paul. The Black Atlantic: Modernity and Double Consciousness. London and New York: Verso, 1993.

Hammond, D., and A. Jablow. "Gilgamesh and the Sundance Kid: The Myth of Male Friendship". Ed. H. Brod. The Making of Masculinities: The New Men's Studies. Boston: Allen and Unwin, (1987): 242-258. 
Kasinitz, Philip. Metropolis: Centre and Symbol of Our Times. New

York: New York University Press, 1995.

Keith, Michael. After the Cosmopolitan?: Multicultural Cities and the Future of Racism. New York: Routledge, 2005.

Lehan, Richard. The City in Literature: An Intellectual and Cultural History. Berkeley: University of California Press, 1998.

Mabro, Robert. "Alexandria 1860-1960: The Cosmopolitan Identity." Alexandria Real and Imagined. Cairo: The American University of Cairo, 2004: 247-262.

Mumford, Lewis. The City in History: Its Origins, Its

Transformations, and lts Prospects. New York: Harcourt Brace and World, 1961.

Oniwe, Bernard Ayo. "Cosmopolitan Conversation and Challenge in Teju Cole's Open City," Ufahamu: A Journal of African Studies, 39(1), (2016): 43-65.

Schwarzenbach, Sibyl A. "On Civic Friendship". Ethics, vol. 107, no.1, October (1996): 97-128.

Sherrod, Drury. "The Bonds of Men. Problems and Possibilities in Close Male Relationships". Ed. H. Brod. The Making of Masculinities: The New Men's Studies. Boston: Allen and Unwin, (1987): 212-239.

Starr, Deborah A. Remembering Cosmopolitan Egypt: Literature, Culture, and Empire. London: New York: Routledge, 2009.

. "Recuperating Cosmopolitan Alexandria: Circulation of Narratives and Narratives of Circulation". Cities, vol.22, no.3, (2005): 217228.

Vermeulen, Pieter. "Flights of Memory: Teju Cole's Open City and the Limits of Aesthetic Cosmopolitanism". Journal of Modern Literature, 37.1, (2013): 40-57.

Wilson, Elizabeth. "The Invisible Flâneur”. New Left Review 191, (19911992): 90-110. 
Wirth-Nesher, Hana. City Codes: Reading the Modern Urban Novel. Cambridge University Press: Cambridge, 1996

\section{صورة المدينة فى رواية "المدينة المفتوحة" لتيجو كول و "لا احد ينام فى الاسكندرية" لابر اهيم عبد المجيد}

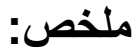

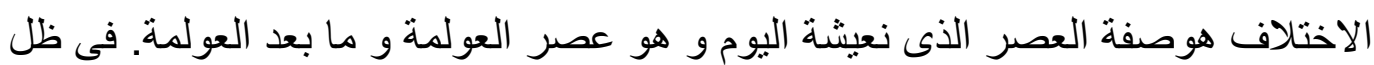

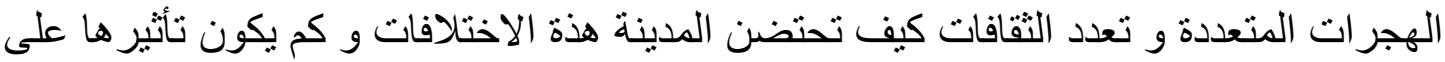

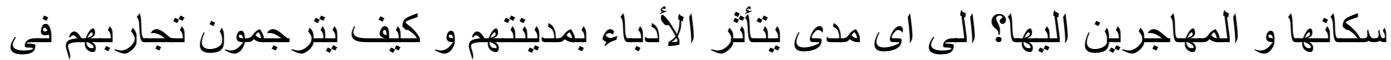

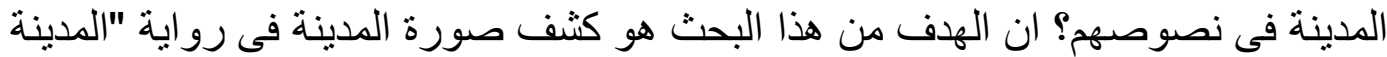
المفتوحة" لتيجو كول و "لا احد ينام فى الاسكندرية" لابر اهيم عبد المجيد. كما بهـف البه البحث

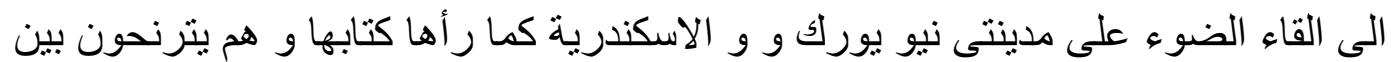
"مدينة المشاعر" و "مدينة الحقائق". 